\title{
Passive Remediation of Acid Mine Drainage Using Ball-Milling Modified Indonesian Natural Bentonite: Laboratory Batch and Column Sorption of Manganese
}

\author{
Widyawanto Prastistho ${ }^{1,2 *}$, Winarto Kurniawan' ${ }^{1}$, Hirofumi Hinode1 \\ ${ }^{1}$ Department of International Development Engineering, Tokyo Institute of Technology, Tokyo, Japan \\ ${ }^{2}$ Department of Environmental Engineering, Universitas Pembangunan Nasional "Veteran”, Yogyakarta, Indonesia \\ Email: *w.prastistho@gmail.com
}

How to cite this paper: Prastistho, W. Kurniawan, W. and Hinode, H. (2018) Passive Remediation of Acid Mine Drainage Using Ball-Milling Modified Indonesian Natural Bentonite: Laboratory Batch and Column Sorption of Manganese. Green and Sustainable Chemistry, 8, 295-310. https://doi.org/10.4236/gsc.2018.84020

Received: September 1, 2018

Accepted: October 7, 2018

Published: October 10, 2018

Copyright (c) 2018 by authors and Scientific Research Publishing Inc. This work is licensed under the Creative Commons Attribution International License (CC BY 4.0).

http://creativecommons.org/licenses/by/4.0/

\section{(c) (i) Open Access}

\begin{abstract}
Manganese ( $\mathrm{Mn})$ is an essential element for human body. However, elevated concentration of manganese causes severe problem and disease. Acid mine drainage (AMD), wastewater generated due to open-pit mining, commonly contains Mn with exceeded concentration. This study is to investigate the improvement of ball-milling modified Indonesian natural bentonite (INB) for manganese $(\mathrm{Mn})$ removal from $\mathrm{AMD}$ and to increase the $\mathrm{pH}$ through batch and column sorption test as a passive treatment system approach. The batch sorption test result showed the maximum $\mathrm{Mn}$ adsorbed $\left(Q_{m}\right)$ on INB from the Langmuir model increased from 4.69 to $17.12 \mathrm{mg} / \mathrm{g}$ after milling. The column sorption test result also showed the amount of Mn adsorbed on INB until breakthrough time $\left(q_{u}\right)$ and until saturation time $(q)$ increased after milling. The $q_{u}$ increased from 1.27 to $10.06 \mathrm{mg} / \mathrm{g}$, and the $q$ increased from 4.55 to $12.91 \mathrm{mg} / \mathrm{g}$. The mass transfer zone (MTZ) became significantly shorter after milling from 0.22 to $0.07 \mathrm{~cm}$. The Thomas model exhibited the equilibrium uptake of $\mathrm{Mn}\left(q_{0}\right)$ increased after milling from 3.91 to $13.72 \mathrm{mg} / \mathrm{g}$. In equilibrium condition, both unmilled and milled INB showed the $\mathrm{pH}$ increased from $\approx 3$ to 8 .
\end{abstract}

\section{Keywords}

Bentonite, Ball-Milling, Manganese, Acid Mine Drainage, Batch and Column Sorption

\section{Introduction}

Acid mine drainage (AMD) is mining wastewater generated when the sulfide 
minerals, such as pyrite $\left(\mathrm{FeS}_{2}\right)$, Galena (PbS), Sphalerite ( $\left.\mathrm{ZnS}\right)$, Alabandite $(\mathrm{MnS})$ are exposed with the oxygen from the atmosphere and the water from rainfall due to excavation (Equation (1)). Acid mine drainage (AMD) has low or near neutral $\mathrm{pH}$ and contains several metals such as iron, manganese, aluminum and also other heavy metals with elevated concentration [1] [2] [3].

$$
2 \mathrm{MS}_{2}+7 \mathrm{O}_{2}+2 \mathrm{H}_{2} \mathrm{O} \rightarrow 2 \mathrm{M}^{2+}+4 \mathrm{SO}_{4}^{2-}+4 \mathrm{H}^{+}
$$

A coal mining located in Jorong, Tanah Laut district, Province of South Kalimantan, Indonesia is reported contained two metal types in the AMD: Mn and Fe with concentration range $1.7-27.2 \mathrm{mg} / \mathrm{L}$ for $\mathrm{Mn}$ and $0.04-3.44 \mathrm{mg} / \mathrm{L}$ for $\mathrm{Fe}$ with $\mathrm{pH} 2.54-3.41$ [4]. The manganese concentration exceeded the quality standard of Indonesian government regulation for mining waste. The Indonesian government set the maximum concentration is $4 \mathrm{mg} / \mathrm{L}$ for $\mathrm{Mn}$ and $7 \mathrm{mg} / \mathrm{L}$ for Fe with the limit of pH 6 - 9 [5]. In fact, manganese is an essential element for the human body. However, high concentration of manganese causes serious problems and diseases such as children hyperactive syndrome, parkinson-like disorder, and neurological symptom due to chronic manganese poisoning [6] [7].

Treatment of AMD is mainly divided into two types "active" and "passive" method. Both methods possibly involving physical, chemical, and biological process, and either has the same main purposes to decrease the metal toxic and raise the $\mathrm{pH}$. The active method refers to continuous reagent addition to neutralize the $\mathrm{pH}$ and remove the metal which involving human assistance for continued operation. In the active system, a fixed plant is required. Conversely, the passive treatment does not need continuous reagent addition and only needs occasional human assistance. Principally, the passive method only passes the AMD through the passive treatment installation such as limestone channel [1] [8] [9].

Passive treatment is more economical compared to active treatment. However, the passive method can only handle low volume and flow rate, low concentration of metals, and mild acidity [8]. Another problem appears most of the passive treatment utilizes the carbonate-based system to increase the $\mathrm{pH}$ and precipitate the metal. In this system, not all metals can be removed due to maximum $\mathrm{pH}$ limitations that can be reached (e.g., manganese cannot be removed completely) [8]. For instance, $\mathrm{Fe}^{2+}$ can be precipitated in $\mathrm{pH} 7-8$, but $\mathrm{Mn}^{2+}$ requires a higher $\mathrm{pH}$ to be precipitated.

Bentonite, a natural clay consisting mostly of montmorillonite minerals, has been widely utilized as a sorbent because it has large surface area and high cation exchange capacity [10]. Some modifications have been developed to improve bentonite sorption performance such as acid activation, pillaring, and milling [11] [12] [13] [14] [15]. Milling itself is mechanically modification technique by applying impact on the sample which affects to morphological change, particle size reduction, structural peeling, exfoliation, and the increase of specific surface area (SSA) and cation exchange capacity (CEC) [14] [16] [17] [18] [19]. Several 
previous studies reported milling-activated bentonite brought to the increase of SSA and CEC which gave better improvement for metals removal [13] [14] [20].

Even though milling modified bentonite has given a satisfying result for metal removal from aqueous solutions and increased the $\mathrm{pH}$, however, the performance in fixed bed column has not been well observed yet. This study purposes to investigate the improvement of milling modified bentonite not only in batch sorption test but also column sorption test as AMD passive treatment approach especially for manganese removal which is still a problem in the AMD passive treatment system. The bentonite used in this study is Indonesian natural bentonite (INB) from Wonosegoro sub-district, province of central Java, Indonesia. This area has a calcium-bentonite type with a hypothetical resource 58 million tons [21] [22].

Clay is known to have a low permeability that would require a long time to transfer the solution from the influent to the effluent. Some previous studies developed clay composite with other material such as sand or other solid matrices to enhance the permeability [23] [24]. However, since this study only focused on the manganese removal improvement after milling modification on bentonite in laboratory column sorption test, the composite of milled bentonite-sand highly recommended for further study.

\section{Material and Methods}

\subsection{Field Sampling and Sample Preparation}

The INB was sampled in nature from claystone geological outcrop, located in Garangan area, Wonosegoro sub-district, Boyolali district, central Java, Indonesia. The INB sample was air-dried and crushed using a mortar and sieved pass between $50-40 \mu \mathrm{m}$. One-gram sieved sample was put inside grind jar (size 50 $\mathrm{ml}$ ) which then milled using Retsch MM 400 for 25 minutes with the vibrational frequency setting was $20 \mathrm{~Hz}$.

\subsection{Characterization}

The morphological changes of INB before and after milling were observed using a scanning electron microscope (SEM) Keyence VE-8800 with 7000 and 5000 times magnifications under vacuum condition. The unmilled and milled INB samples were gold coated before the observation in the SEM. The crystallinity changes before and after milling were observed using x-ray diffraction (XRD) equipment Rigaku Multiflex with $\mathrm{Cu}$ source, operated at $40 \mathrm{kV}$ and $20 \mathrm{~mA}$, measurement angle from $3^{\circ}-30^{\circ}$. The CEC of unmilled and milled INB samples were determined using the Chapman method by saturating the samples with sodium acetate and then replaced the sodium with ammonium acetate [25]. The surface functional groups of montmorillonite mineral of INB before and after milling were recorded using Jasco FT/IR-6100FV Fourier Transform Infrared (FTIR) in the range of $800-1200 \mathrm{~cm}^{-1}$. The sample preparation for FTIR was by mixing $1 \mathrm{mg}$ sample with $10 \mathrm{mg}$ potassium bromide $(\mathrm{KBr})$ and followed by pel- 
letizing.

\subsection{Batch and Sorption Study}

\subsubsection{Effect of Contact Time}

Manganese solutions with $24 \mathrm{mg} / \mathrm{L}$ in concentration were prepared by diluting from $\mathrm{Mn}\left(\mathrm{NO}_{3}\right)_{2}$ Wako standard solution $1000 \mathrm{ppm}$. The $\mathrm{pH}$ was set 2.8 by adding $\mathrm{H}_{2} \mathrm{SO}_{4}$. The solutions were prepared in two portions with volume $50 \mathrm{~mL}$ respectively in beaker glass. Unmilled and milled INB with mass $0.1 \mathrm{~g}$ respectively were added into each solution prepared in beaker glass. A magnetic stirrer was used to mix the sample and solution with 320 rotations per minute (RPM) at room temperature. The mixture was sampled at $10 \mathrm{~min}, 20 \mathrm{~min}, 30 \mathrm{~min}, 1 \mathrm{~h}, 2 \mathrm{~h}$, $4 \mathrm{~h}, 6 \mathrm{~h}$, and $8 \mathrm{~h}$.

\subsubsection{Effect of Adsorbate Concentration}

Five different concentrations of manganese solutions were prepared: 6.5, 13.1, $24,43.3$, and $83 \mathrm{mg} / \mathrm{L}$. Each concentration was prepared in two portions with volume $50 \mathrm{~mL}$ respectively in beaker glass. Unmilled and milled INB with $0.1 \mathrm{~g}$ in mass respectively were added into each different concentration solution prepared in beaker glass. The stirrer was set at 320 RPM at room temperature until equilibrium condition.

\subsubsection{Effect of Different $\mathrm{pH}$}

Five different $\mathrm{pHs}$ of $24 \mathrm{mg} / \mathrm{L}$ manganese solutions were prepared: 2.8, 3.9, 5.1, 6.7, and 7.9 with volume $50 \mathrm{~mL}$ respectively in beaker glass. The $\mathrm{pH}$ was adjusted using $\mathrm{H}_{2} \mathrm{SO}_{4}$ in order to obtain lower value and using $\mathrm{NaOH}$ in order to obtain higher value. Each $\mathrm{pH}$ was prepared in two portions. $0.1 \mathrm{~g}$ of unmilled and milled sample was added each of it. The stirrer was also set 320 RPM at room temperature until equilibrium condition.

Adsorbed Mn on INB was calculated using Equation (2).

$$
q=\frac{C_{0}-C_{e}}{m} V
$$

where, $q$ = adsorbed manganese on sample $(\mathrm{mg} / \mathrm{g}), C_{0}=$ initial concentration $(\mathrm{mg} / \mathrm{L}), C_{e}=$ final concentration $(\mathrm{mg} / \mathrm{L}), V=$ solution volume $(\mathrm{ml}), m=$ sample mass (g).

\subsubsection{Adsorption Isotherm}

Adsorption is usually explained using isotherm that described the relationship between the amount of adsorbate on the adsorbent and the solution concentration in equilibrium condition. Langmuir is a fitting model that assumes monolayer adsorption on the surface of adsorbent while the Brunauer Emmet Teller (BET) is a fitting model used for assuming the adsorption is multilayer on the surface [26].

\subsection{Column Sorption Study}

The column sorption test was conducted in a plastic syringe column with di- 
ameter of $1.6 \mathrm{~cm}$. The sample with $0.5 \mathrm{~g}$ in mass was added into the syringe with the fixed filter at the bottom and top of the sample. The thickness of the sample in the syringe column was $0.3 \mathrm{~cm}$. The stock of manganese solution in influent was prepared from the top of the syringe column with concentration $24 \mathrm{mg} / \mathrm{L}$ and $\mathrm{pH}$ 2.8. A vacuum pump was applied on a vacuum chamber which took up the solution from the bottom of syringe column through the valve. The column test setup is depicted in Figure 1. The flow rate was set at $0.8 \mathrm{~mL} / \mathrm{min}$ and kept in constant by controlling the pressure adjuster.

The concentration of all sample solutions taken from batch and column test was measured using induced coupled plasma atomic emission spectroscopy (ICP-AES) Seiko Instrument, SPS 7800 (II).

\section{Result and Discussion}

\subsection{Characterization}

The morphology of INB before and after milling is displayed in Figure 2. The unmilled bentonite shows angular particles in aggregate. After milling the morphology shows less angularity, more destructed, and crumbled.

The influence of milling on montmorillonite structure can be seen in Figure 3. After 25 minutes of milling, the peak of (001) montmorillonite cannot be observed, the intensity of (100) montmorillonite significantly decreased, and the peak is shifted to the higher degree of 2 theta. The decrease of montmorillonite intensity can be interpreted the crystal structure of montmorillonite started to be amorphized after 25 minutes of milling. The shifted peak indicates the decrease of the cell volume of the crystal due to the press effect of milling.

More detailed explanation about the change in the montmorillonite structure after milling was obtained from FTIR spectroscopy that presented in Figure 4. The assignment of bands is according to Srasra et al. (1994) [27] and Tyagi, et al. (2006) [28]. Two OH bending groups in the dioctahedral sheet of montmorillonite indicated by $854 \mathrm{~cm}^{-1}$ (Al-Mg-OH) and $915 \mathrm{~cm}^{-1}$ (Al-Al-OH) [27]. The $\mathrm{Si}-\mathrm{O}-\mathrm{Si}$ bond in the tetrahedral sheet of montmorillonite indicated by $1031 \mathrm{~cm}^{-1}$ [28]. The FTIR result confirmed the deformation of montmorillonite structure by straightening peak of $\mathrm{Al}-\mathrm{Mg}-\mathrm{OH}$ bending and a significant decrease of $\mathrm{Al}-\mathrm{Al}-\mathrm{OH}$ bending intensity after 25 minutes of milling while the Si-O-Si stretching remained.

The CEC of unmilled and milled INB was observed to be $17 \mathrm{meq} / 100 \mathrm{~g}$ and 35 meq/100g. The deformation of the montmorillonite structure did not decrease the cation exchange capacity instead. It can be interpreted the broken of the octahedral sheet after 25 minutes milling which caused loss of $\mathrm{Mg}$ cation (from FTIR result) affected the increase of negative surface charge of montmorillonite.

\subsection{Batch Sorption Study}

\subsubsection{Effect of Contact Time}

The effect of contact time on the sorption of manganese is shown in Figure 5. 
After milling the INB showed a significant increase in adsorption capacity. The adsorption rate of both samples initially increased rapidly and reached the equilibrium in 2 hours. The pH of unmilled and milled INB increased became 8 in equilibrium condition.

\subsubsection{Effect of Adsorbate Concentration}

Variation of Mn removal in various concentrations is shown in Figure 6. As the Mn concentrations increased, the percentage removal decreased. When the Mn concentration is low, more surfaces are available to adsorb the Mn. In contrary, when the Mn concentration is high, the adsorption surfaces become fewer for the Mn to be adsorbed. The milled INB shows an increase in removal percentage compared to the unmilled around $27 \%-40 \%$.

\subsubsection{Effect of Different $\mathrm{pH}$}

The effect of different $\mathrm{pH}$ on $\mathrm{Mn}$ sorption from solution is shown in Figure 7. It can be observed that the sorption of $\mathrm{Mn}$ increases with the increase of $\mathrm{pH}$ in the solutions. Montmorillonite mineral is known to possess a negative surface charge due to isomorphic substitution in octahedral sheet [29] [30]. The change of $\mathrm{pH}$ will also change the surface charge of montmorillonite. In lower $\mathrm{pH}$, protonation on the tetrahedral sheet surface of montmorillonite tends to intense which cause the decrease in surface charge. Hence, lower $\mathrm{pH}$ causes lesser $\mathrm{Mn}$ adsorbed on bentonite, and higher $\mathrm{pH}$ will affect more Mn adsorbed. The milled INB also shows better percentage removal than the unmilled corresponds to the increase of CEC.

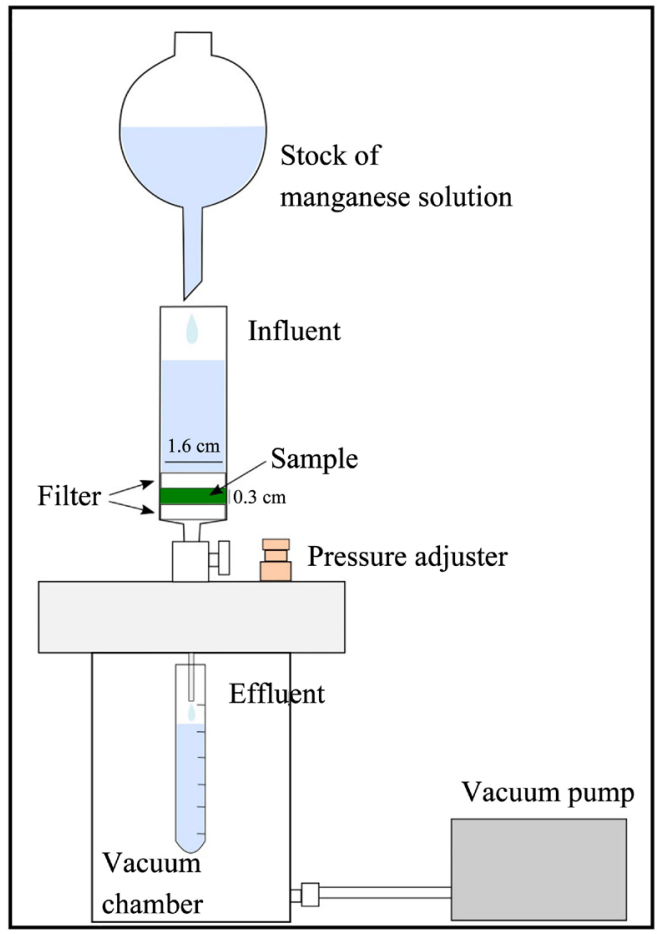

Figure 1. Schematic of column test setup. 

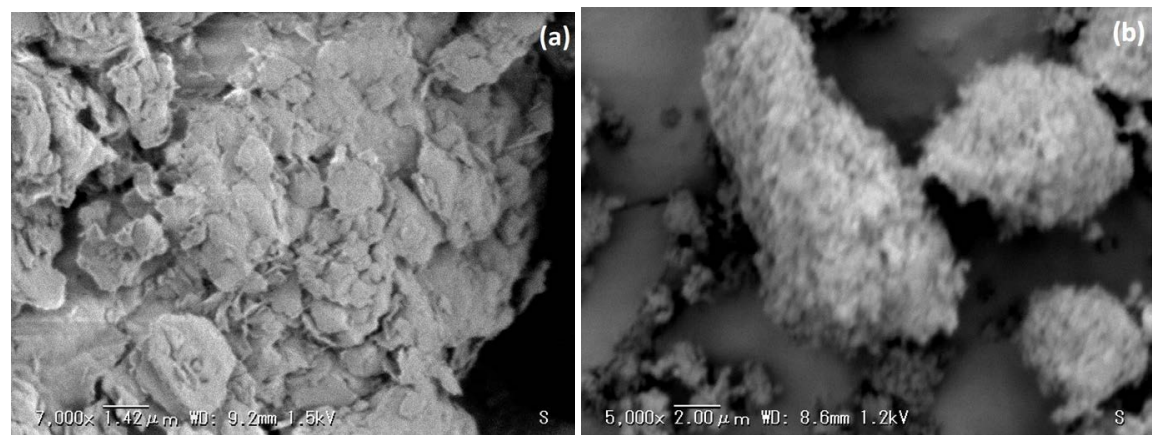

Figure 2. SEM images (a) before milling and (b) after milling.

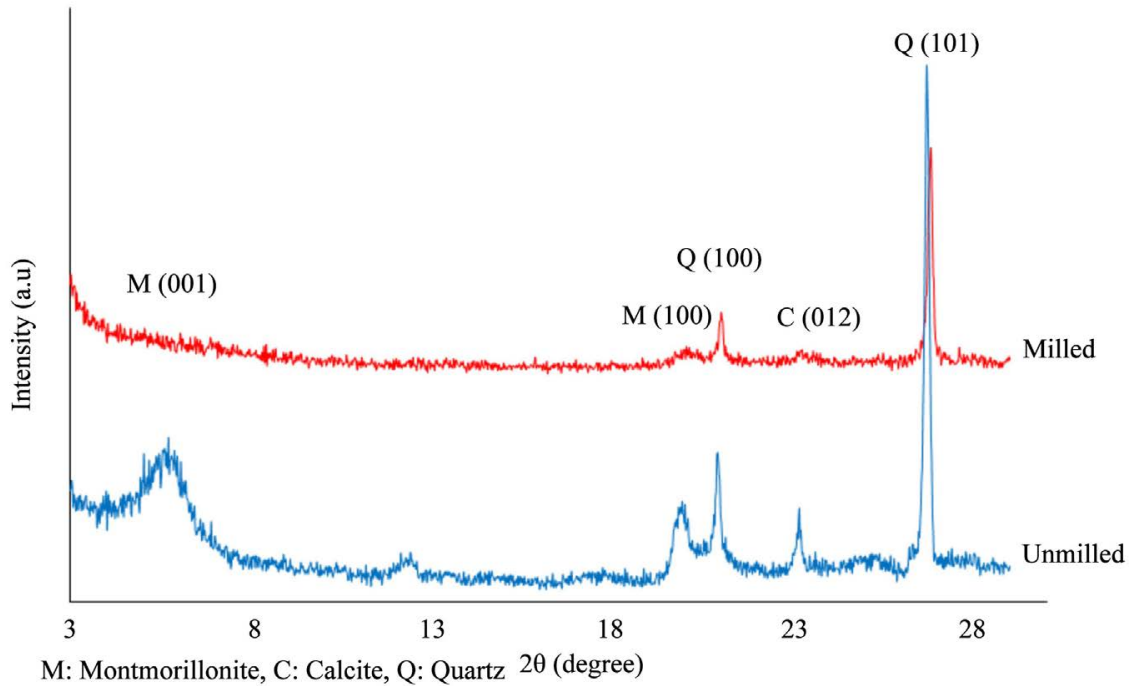

Figure 3. XRD pattern of unmilled and milled INB.

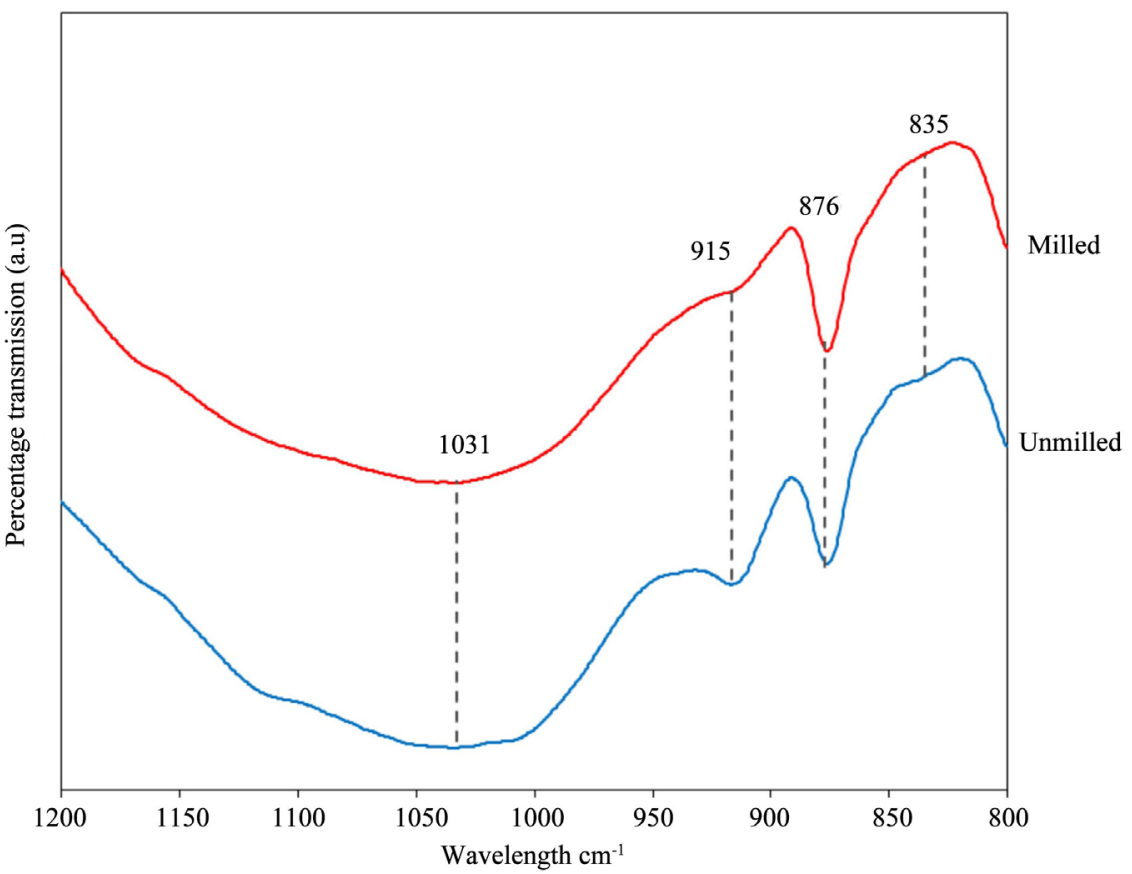

Figure 4. FTIR spectra of unmilled and milled INB. 


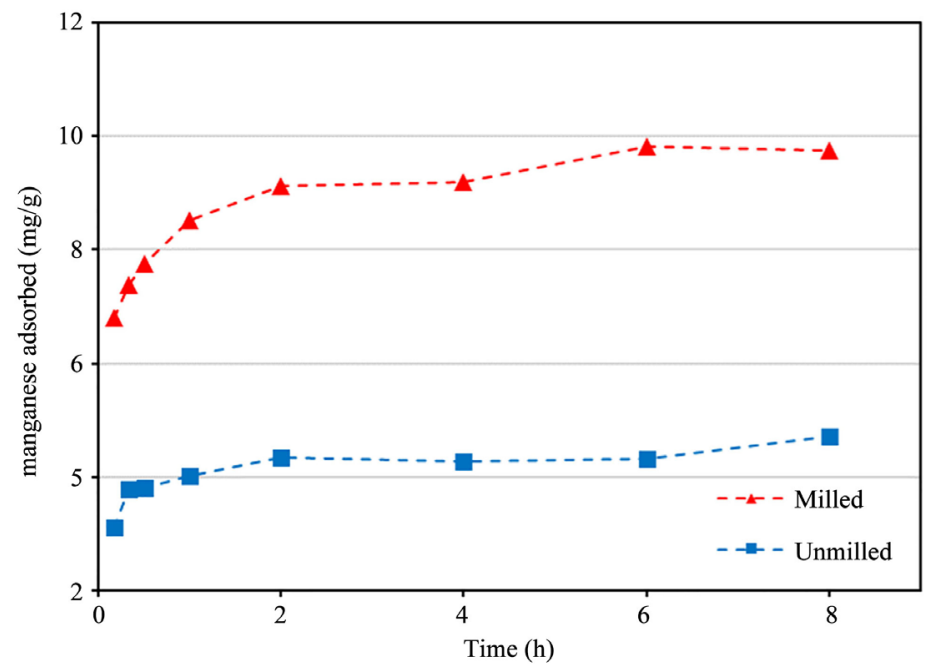

Figure 5. Effect of contact time of manganese sorption.

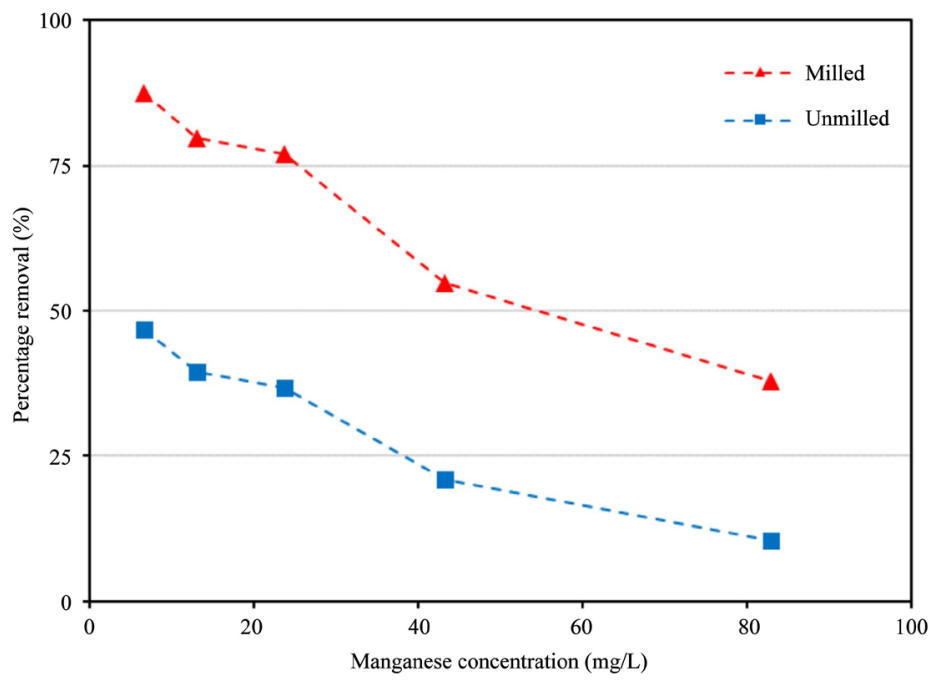

Figure 6. Effect of adsorbate concentration of manganese sorption.

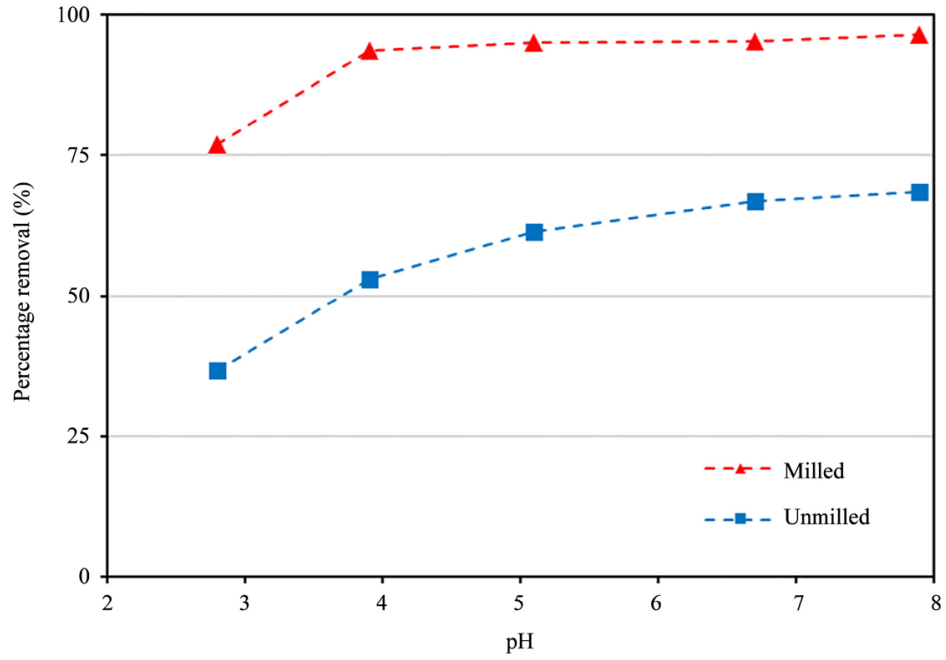

Figure 7. Effect of different $\mathrm{pH}$. 


\subsubsection{Adsorption Isotherms}

The relationship between the amount of $\mathrm{Mn}$ adsorbed and the concentration remaining in solution was investigated. The Langmuir model is described by Equation (3):

$$
q=\frac{Q_{m} k C_{e}}{1+k C_{e}}
$$

In order to get the Langmuir constant $k$ and $Q_{m}$ (maximum adsorbate adsorbed on adsorbent) the Equation (3) is linearized into Equation (4):

$$
\frac{C_{e}}{q_{e}}=\frac{1}{Q_{m} k}+\frac{C_{e}}{Q_{m}}
$$

where, $C_{e}=$ equilibrium concentration $(\mathrm{mg} / \mathrm{L}), q_{e}=$ amount of adsorbate adsorbed on adsorbent at equilibrium, $Q_{m}=$ maximum adsorbate adsorbed on adsorbent $(\mathrm{mg} / \mathrm{g})$, and $k=$ Langmuir constant.

The BET model is formulated in Equation (5):

$$
q_{e}=\frac{k_{B E T} C_{e} Q_{m}}{\left(C_{0}-C_{e}\right)\left(1+\left(k_{B E T}-1\right)\right)\left(\frac{C_{e}}{C_{0}}\right)}
$$

The BET equation can be linearized as in Equation (6):

$$
\frac{C_{e}}{q_{e}\left(C_{0}-C_{e}\right)}=\frac{\left(1+\left(k_{B E T}-1\right)\right)\left(\frac{C_{e}}{C_{0}}\right)}{k_{B E T} Q_{m}}
$$

where, $C_{e}=$ equilibrium concentration $(\mathrm{mg} / \mathrm{L}), q_{e}=$ amount of adsorbate adsorbed on adsorbent at equilibrium, $Q_{m}=$ maximum adsorbate adsorbed on adsorbent $(\mathrm{mg} / \mathrm{g}), k_{B E T}=$ constant corresponding to the energy of sorption.

The Langmuir and BET plot of unmilled and milled INB can be seen in Figure 8 and Figure 9. The parameter can be seen in Table 1 which shows that the sorption data fitted well to Langmuir isotherms than the BET. The correlation coefficient $\left(R^{2}\right)$ of the Langmuir isotherms of both unmilled and milled sample shows 0.99 . The maximum $\mathrm{Mn}$ adsorbed on the sample shows significant improvement almost four times after milling.

The interesting finding in this investigation is the increase of $R^{2}$ in BET isotherm after milling. Ca-bentonite is known to have a diffuse double layer on the outer surface of tactoids of montmorillonite minerals while in internal surface or interlayer only forms monolayer cations without diffuse double layer [31]. Previous studies described milling had affected clay mineral shifting along the basal plane [32] [33]. In this study allegedly, there is a development of secondary active sites on bentonite after milling due to the shifting of montmorillonite array. This shifting yielded more new surfaces to formed new diffuse double layer. The increase of $R^{2}$ in BET isotherms after milling is probably indicated the development of multilayer sorption in response to the development of diffuse double layer. 


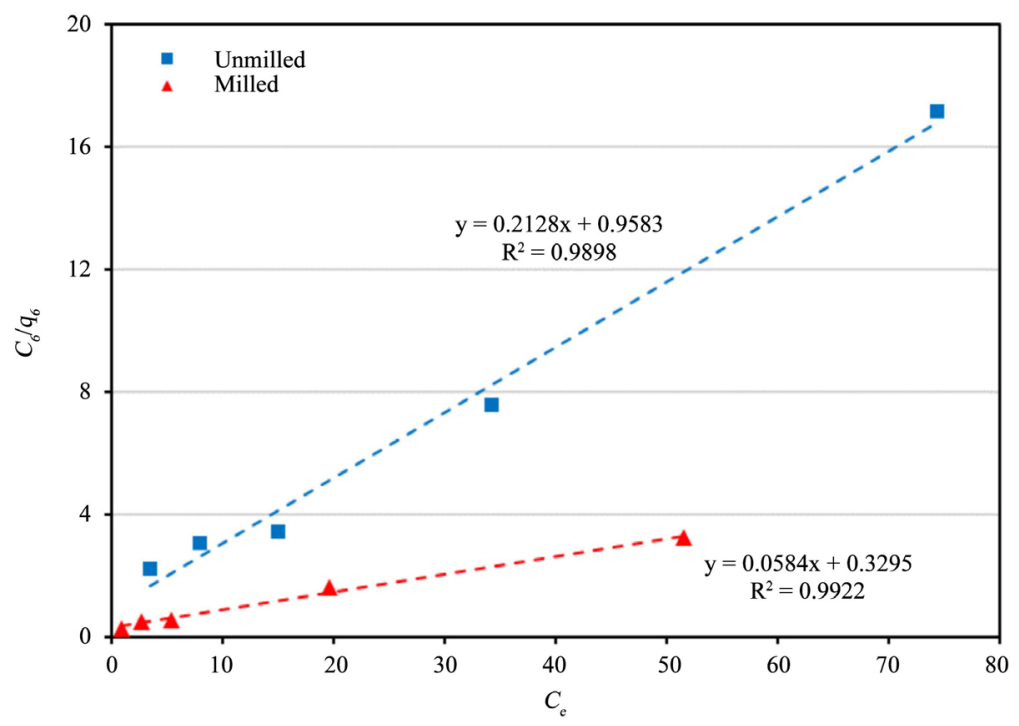

Figure 8. Langmuir isotherms.

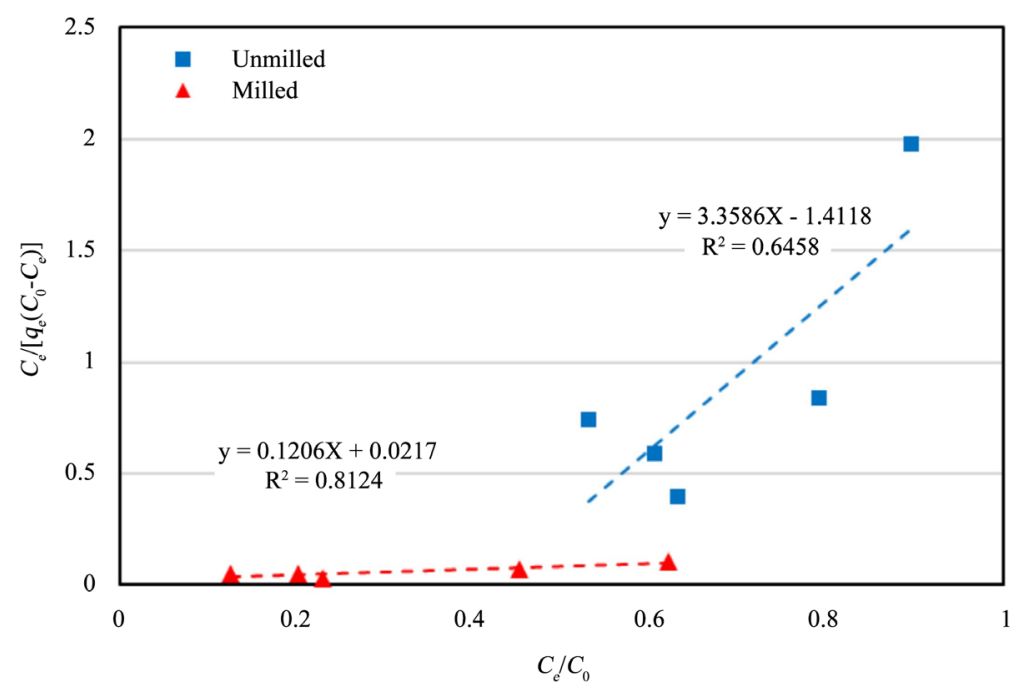

Figure 9. BET isotherms.

Table 1. Parameters of Langmuir and BET isotherms.

\begin{tabular}{ccccccc}
\hline \multirow{2}{*}{$\begin{array}{c}\text { Sample } \\
\text { condition }\end{array}$} & \multicolumn{3}{c}{ Langmuir } & \multicolumn{3}{c}{ BET } \\
\cline { 2 - 7 } & $R^{2}$ & $Q_{m}(\mathrm{mg} / \mathrm{g})$ & $k(\mathrm{~L} / \mathrm{mg})$ & $R^{2}$ & $Q_{m}(\mathrm{mg} / \mathrm{g})$ & $k_{B E T}(\mathrm{~L} / \mathrm{mg})$ \\
\hline Unmilled & 0.99 & 4.69 & 0.22 & 0.64 & 1.19 & -3.74 \\
Milled & 0.99 & 17.12 & 0.17 & 0.81 & 45.96 & 1.00 \\
\hline
\end{tabular}

\subsection{Column Sorption Study}

\subsubsection{Dynamic Experiment}

Effect milling on INB in dynamic sorption experiment was investigated. In this study breakthrough time was set when the concentration in the effluent reached $4 \mathrm{mg} / \mathrm{L}(\mathrm{C} / \mathrm{Co}=0.17)$, referring to Indonesian government regulation of the maximum limit of Mn concentration for mining waste [5]. Breakthrough curves 
of unmilled and milled INB are depicted in Figure 10. In the same flow rate, bed length, and initial concentration of the influent solution, unmilled INB reaches breakthrough time $\left(t_{b}\right)$ faster than milled INB. The breakthrough times are 37 minutes for the unmilled and 277 minutes for the milled INB. The saturation times (sat) are 363 minutes for the unmilled and 473 minutes for the milled INB. This indicates milled INB adsorbed Mn more than the unmilled in fixed bed column sorption test.

The $\mathrm{pH}$ of the effluent from both unmilled and milled INB was measured at 6 minutes (first sample at service time), during breakthrough, and equilibrium. Both unmilled and milled showed $\mathrm{pH} 8$ in the three conditions above.

The amount of metal adsorbed until $t_{b}$ and sat is expressed in Equation (7) and Equation (8) as follows:

$$
\begin{gathered}
q_{u}=\frac{C_{0} F}{m} \int_{0}^{t_{b}}\left(1-\frac{C}{C_{0}}\right) d t \\
q=\frac{C_{0} F}{m} \int_{0}^{\infty}\left(1-\frac{C}{C_{0}}\right) d t
\end{gathered}
$$

where, $C_{0}=$ initial concentration $(\mathrm{mg} / \mathrm{L}), F=$ flow rate $(\mathrm{mL} / \mathrm{min}), m=$ mass of adsorbent $(\mathrm{g})$. The calculation of mass transfer zone length (MTZ) used a simplified equation stated in Equation (9) introduced by Geankoplis (1993) [34].

$$
M T Z=\left(1-\frac{q_{u}}{q}\right) H t
$$

where, $H t=$ total height of $(\mathrm{cm})$.

All of the breakthrough parameters calculation is presented in Table 2. The milled INB exhibits better performance for Mn removal which indicated by an increase in Mn uptake after ball milling modification.

\subsubsection{Bed Modeling}

Dynamic behavior description of adsorbate adsorption into adsorbent is one essential factor for successful design of fixed-bed column adsorption process. In the kinetic model, Thomas model is one of the models which widely and commonly used to predict the performance of column operation. The adsorption rate constant and the uptake of adsorbate can be determined using this model. Thomas model is derived from Langmuir kinetics at equilibrium and neglects the axial and radial dispersion [35]. The Thomas solution is written in Equation (10).

$$
\frac{C_{t}}{C_{0}}=\frac{1}{1+\exp \left[\left(\frac{k_{T H} q_{0} m}{v}\right)-k_{T H} C_{0} t\right]}
$$

The linearized Thomas model can be expressed in Equation (11).

$$
\ln \left(\frac{C_{0}}{C_{t}}-1\right)=\frac{k_{T H} q_{0} m}{v}-k_{T H} C_{0} t
$$


where, $k_{T h}=$ Thomas rate constant (L/min.mg), $q_{0}=$ equilibrium uptake of adsorbate $(\mathrm{mg} / \mathrm{g}), C_{0}=$ influent concentration $(\mathrm{mg} / \mathrm{L}), C_{t}=$ effluent concentration at time $(t)(\mathrm{min}), V=$ flow rate $(\mathrm{mL} / \mathrm{min})$. The linier regression analysis for breakthrough curve using Thomas model is depicted in Figure 11 and the parameter is presented in Table 3.

Comparisons between the predicted curve of Thomas model and the experimental curve are shown in Figure 12. The figure shows the experimental curve becomes fit to the model and has sigmoid shaped after milling. The $R^{2}$ value becomes higher and closer to 1 after milling. It is assumed the INB became more homogenous with the increase of CEC after milling.

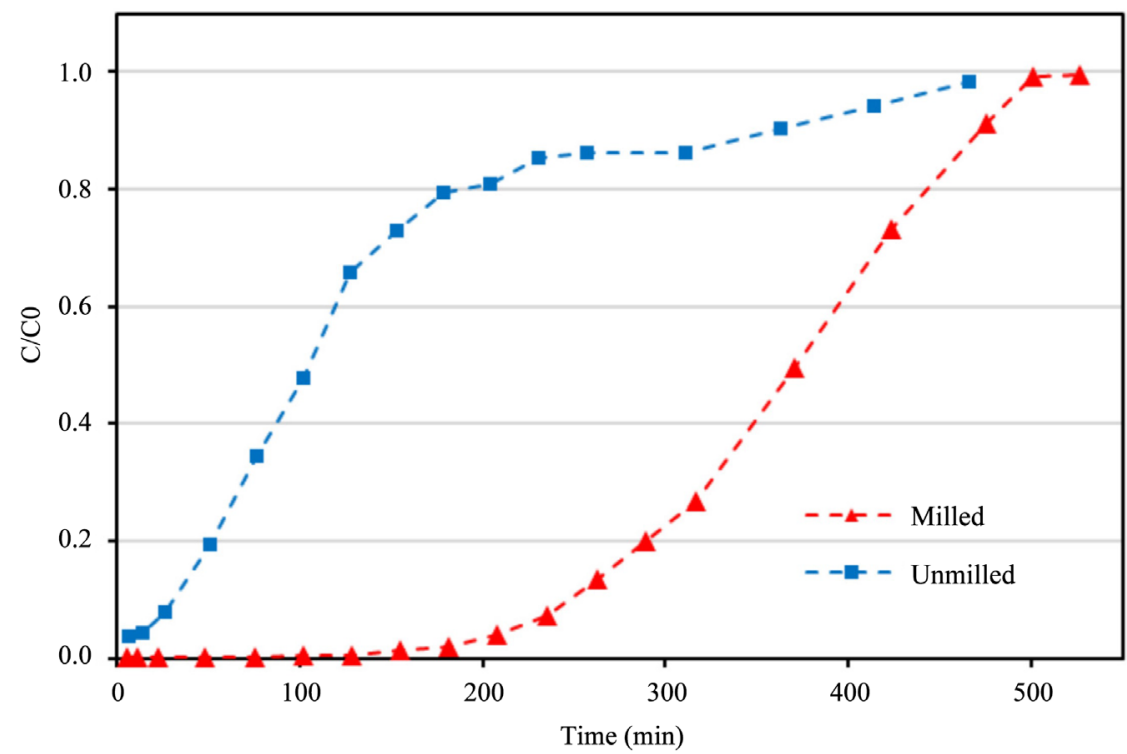

Figure 10. Breakthrough curves of unmilled and milled INB.

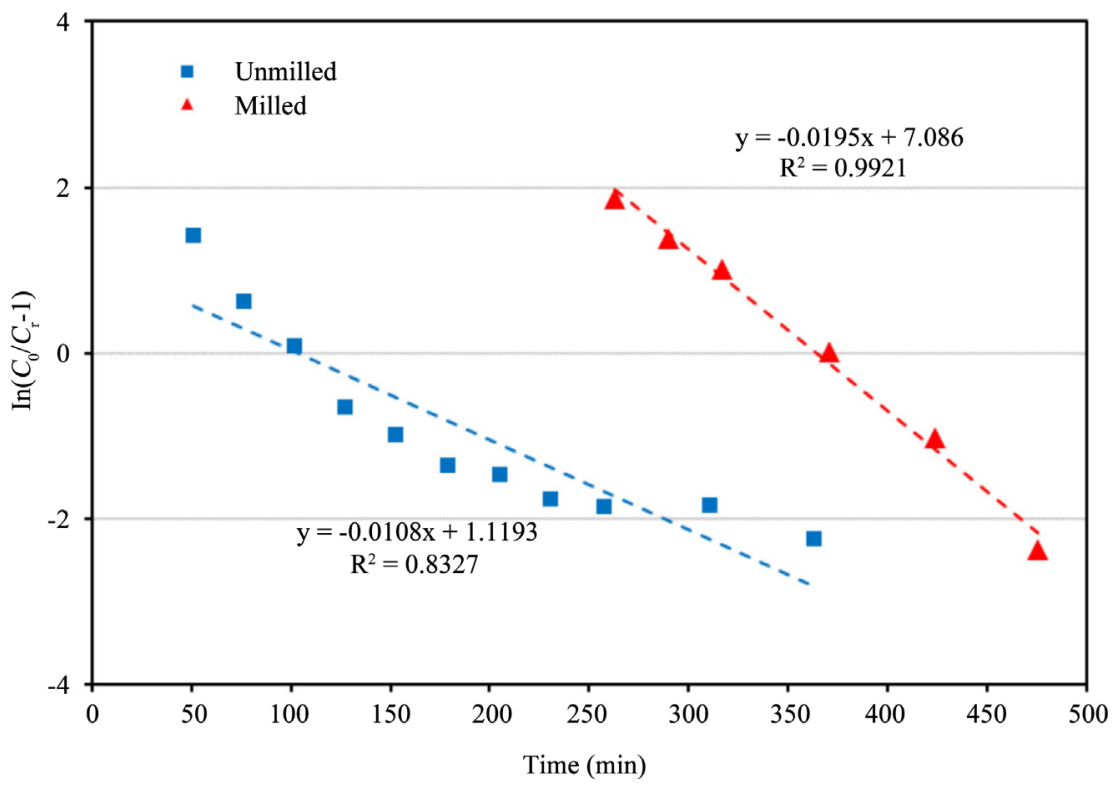

Figure 11. Linear Thomas model fit of breakthrough data for Mn sorption on INB. 


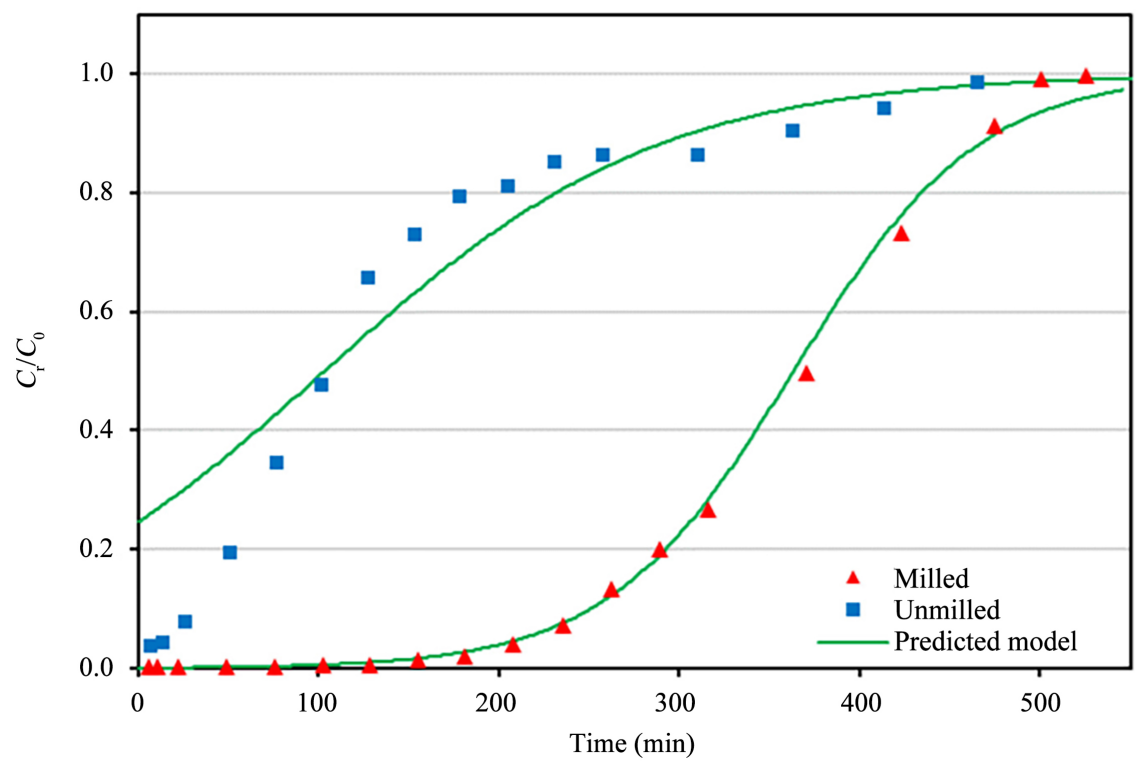

Figure 12. Comparison between the predicted curves of Thomas model with experimental data.

Table 2. Parameters of breakthrough curve.

\begin{tabular}{cccc}
\hline Sample & $q_{u}(\mathrm{mg} / \mathrm{g})$ & $q(\mathrm{mg} / \mathrm{g})$ & $M T Z(\mathrm{~cm})$ \\
\hline Unmilled & 1.27 & 4.55 & 0.22 \\
Milled & 10.06 & 12.91 & 0.07 \\
\hline
\end{tabular}

Table 3. Thomas model parameters.

\begin{tabular}{cccc}
\hline \multirow{2}{*}{ Sample } & \multicolumn{3}{c}{ Thomas model } \\
\cline { 2 - 4 } & $K_{\text {Th }}(\mathrm{L} / \mathrm{min} \cdot \mathrm{mg})$ & $q_{0}(\mathrm{mg} / \mathrm{g})$ & $R^{2}$ \\
\hline Unmilled & $4.6 \times 10^{-4}$ & 3.91 & 0.83 \\
Milled & $8.3 \times 10^{-4}$ & 13.72 & 0.99 \\
\hline
\end{tabular}

\section{Conclusions}

Ball milling on INB has significantly improved the manganese removal from simulated AMD. Batch sorption test result showed better performance after milling with the significant increase of sorption capacity of INB on manganese. Column sorption test result as the passive treatment system approach showed the effect of ball milling on INB brought significant improvement by showing longer breakthrough time, higher manganese removal, and shorter MTZ. The shorter MTZ indicated the bed sorbent became more efficient for column sorption operation. The $\mathrm{pH}$ also showed desired values from both batch and column sorption result in equilibrium conditions.

Since the bentonite has a low permeability, the composite of milled bentonite-sand to obtain more permeable bed remediation is highly recommended for further study. 


\section{Acknowledgements}

This experiment was supported by Hinode laboratory, Department of International Development Engineering, Tokyo Institute of Technology, Japan. The field sampling was supported by Dr. Wawan Budianta, Environmental Geology laboratory, Department of Geological Engineering, Gadjah Mada University, Yogyakarta, Indonesia.

\section{Conflicts of Interest}

The authors declare no conflicts of interest regarding the publication of this paper.

\section{References}

[1] Johnson, D.B. and Hallberg, K.B. (2005) Acid Mine Drainage Remediation Options: A Review. Science of the Total Environment, 338, 3-14. https://doi.org/10.1016/j.scitotenv.2004.09.002

[2] Akcil, A. and Koldas, S. (2006) Acid Mine Drainage (AMD): Causes, Treatment and Case Studies. Journal of Cleaner Production, 14, 1139-1145. https://doi.org/10.1016/j.jclepro.2004.09.006

[3] Ziemkiewicz, P.F., Brant, D.L. and Skousen, J.G. (1996) Acid Mine Drainage Treatment with Open Limestone Channels. Proceedings American Society of Mining and Reclamation, Knoxville, Tennessee, 19-25 May 1996, 367-374. https://doi.org/10.21000/JASMR96010367

[4] Herniwanti, Priatmadi, J.B., Yanuwiadi, B. and Soemarno (2014) Characteristics of Acid Mine Water. International Journal of ChemTech Research, 6, 967-972.

[5] Indonesian Ministry of Life Environment (2003) Standard Quality for Coal Mining Waste Water. Indonesia.

[6] Bouchard, M., Laforest, F., Vandelac, L., Bellinger, D. and Mergler, D. (2007) Hair Manganese and Hyperactive Behaviors: Pilot Study of School Age Children Exposed Through Tap Water. Environmental Health Perspective, 115, 122-127. https://doi.org/10.1289/ehp.9504

[7] Kondakis, X.G., Makris, N., Leotsinidis, M., Prinou, M. and Papapetropoulos, T. (1989) Possible Health Effects of High Manganese Concentrations in Drinking Water. Archives of Environmental Health, 44, 175-178. https://doi.org/10.1080/00039896.1989.9935883

[8] Taylor, J., Pape, S. and Murphy, N. (2005) A Summary of Passive and Active Treatment Technologies for Acid and Metalliferous Drainage (AMD). Proceedings of the 5 th Australian Workshop on Acid Drainage, Fremantle, Western Australia, 29-31 August 2005, 1-49.

[9] Zipper, C., Skousen, J. and Jage, C. (2011). Passive Treatment of Acid-Mine Drainage. Virginia Cooperative Extension, 23, 1338-1345.

[10] Arledge, P.A. (2015) Calcium Bentonite Clay: Nature's Pathway to Healing Balance, Detox, Stimulate, Alkalize. Xlibris US, Bloomington.

[11] Budsaereechai, S., Kamwialisak, K. and Ngernyen, Y. (2012) Adsorption of Lead, Cadmium and Copper on Natural and Acid Activated Bentonite Clay. KKU Research Journal, 17, 800-810.

[12] El Miz, M., et al. (2014) Characterization and Adsorption Study of Thymol on Pil- 
lared Bentonite. Open Journal of Physical Chemistry, 4, 98-116. https://doi.org/10.4236/ojpc.2014.43013

[13] Vhahangwele, M. and Mugera, G.W. (2015) The Potential of Ball-Milled South African Bentonite Clay for Attenuation of Heavy Metals from Acidic Wastewaters: Simultaneous Sorption of $\mathrm{Co}^{2+}, \mathrm{Cu}^{2+}, \mathrm{Ni}^{2+}, \mathrm{Pb}^{2+}$, and $\mathrm{Zn}^{2+}$ Ions. Journal of Environmental Chemical Engineering, 3, 2416-2425.

https://doi.org/10.1016/j.jece.2015.08.016

[14] Djukić, A., Jovanović, U., Tuvić, T., Andrić, V., Grbović Novaković, J., Ivanović, N. and Matović, L. (2013) The Potential of Ball-Milled Serbian Natural Clay for Removal of Heavy Metal Contaminants from Wastewaters: Simultaneous Sorption of $\mathrm{Ni}, \mathrm{Cr}, \mathrm{Cd}$ and $\mathrm{Pb}$ Ions. Ceramics International, 39, 7173-7178.

https://doi.org/10.1016/j.ceramint.2013.02.061

[15] Bhattacharyya, K.G. and Sen, S. (2011) Removal of Cu (II) by Natural and Acid-Activated Clays: An Insight of Adsorption Isotherm, Kinetic and Thermodynamics. Desalination, 272, 66-75. https://doi.org/10.1016/j.desal.2011.01.001

[16] Ramadan, A.R., Esawi, A.M.K. and Gawad, A.A. (2010) Effect of Ball Milling on the Structure of $\mathrm{Na}^{+}$-Montmorillonite and Organo-Montmorillonite (Cloisite 30B). Applied Clay Science, 47, 196-202. https://doi.org/10.1016/j.clay.2009.10.002

[17] Christidis, G.E., Dellisanti, F., Valdre, G. and Makri, P. (2005) Structural Modifications of Smectites Mechanically Deformed under Controlled Conditions. Clay Minerals, 40, 511-522. https://doi.org/10.1180/0009855054040188

[18] Lee, Y.C., Kuo, C.L., Wen, S.B. and Lin, C.P. (2007) Changes of Organo-Montmorillonite by Ball-Milling in Water and Kerosene. Applied Clay Science, 36, 265-270. https://doi.org/10.1016/j.clay.2006.09.013

[19] Christidis, G.E., Makri, P. and Perdikatsis, V. (2004) Influence of Grinding on the Structure and Colour Properties of Talc, Bentonite and Calcite White Fillers. Clay Minerals, 39, 163-175. https://doi.org/10.1180/0009855043920128

[20] Masindi, V., Gitari, M.W., Tutu, H. and DeBeer, M. (2015) Efficiency of Ball Milled South African Bentonite Clay for Remediation of Acid Mine Drainage. Journal of Water Process Engineering, 8, 227-240. https://doi.org/10.1016/j.jwpe.2015.11.001

[21] Indonesian Ministry of Energy and Mineral Resource (2009) Book 3: Java Island, Indonesian Geological Resource, Indonesian Ministry of Energy and Mineral Resource, Indonesia.

[22] Yulianti, A., Warmada, I.W. and Titisari, A.D. (2011) Characteristics and Genesis of Montmorilonitic Claystone from Bandung Area, Wonosegoro, Boyolali, Central Java, Indonesia. Journal of Southeast Asian Applied Geology, 3, 64-71.

[23] Ake, C.L., et al. (2003) Porous Organoclay Composite for the Sorption of Polycyclic Aromatic Hydrocarbons and Pentachlorophenol from Groundwater. Chemosphere, 51, 835-844. https://doi.org/10.1016/S0045-6535(03)00040-7

[24] Ake, C.L., Mayura, K., Huebner, H., Bratton, G.R. and Phillips, T.D. (2001) Development of Porous Clay-Based Composites for the Sorption of Lead from Water. Journal of Toxicology and Environmental Health, 63, 459-475. https://doi.org/10.1080/152873901300343489

[25] Chapman, H.D. (1965) Cation Exchange Capacity. In: Black, C.A., Ed., Methods of Soil Analysis-Chemical and Microbiological Properties, American Society of Agronomy Inc., Madison, 891-901.

[26] Do, D.D. (1998) Adsorption Analysis: Equilibira and Kinetics. Vol. 2, Imperial College Press, London.

[27] Srasra, E., Bergaya, F. and Fripiat, J.J. (1994) Infrared Spectroscopy Study of Tetra- 
hedral and Octahedral Substitutions in an Interstratified Illite-Smectite Clay. Clays and Clay Minerals, 42, 237-241. https://doi.org/10.1346/CCMN.1994.0420301

[28] Tyagi, B., Chudasama, C.D. and Jasra, R.V. (2006) Determination of Structural Modification in Acid Activated Montmorillonite Clay by FT-IR Spectroscopy. Spectrochimica Acta-Part A: Molecular and Biomolecular Spectroscopy, 64, 273-278. https://doi.org/10.1016/j.saa.2005.07.018

[29] Grim, R.E. (1968) Clay Mineralogy. McGraw Hill Book Company, New York, NY.

[30] Essington, M.E. (2004) Soil and Water Chemistry: An Integrative Approach. CRC Press, Boca Raton. https://doi.org/10.1201/b12397

[31] Blackmore, A.V. and Miller, R.D. (1961) Tactoid Size and Osmotic Swelling in Calcium Montmorillonite. Soil Science Society of America Journal, 25, 169-173. https://doi.org/10.2136/sssaj1961.03615995002500030009x

[32] Prastistho, W., Kurniawan, W. and Hinode, H. (2018) Ball-Milling Effect on Indonesian Natural Bentonite for Manganese Removal from Acid Mine Drainage. MATEC Web of Conferences, 156, 1-5.

[33] Sondi, I., Stubičar, M. and Pravdić, V. (1997) Surface Properties of Ripidolite and Beidellite Clays Modified by High-Energy Ball Milling. Colloids and Surfaces A: Physicochemical and Engineering Aspects, 127, 141-149. https://doi.org/10.1016/S0927-7757(96)03893-9

[34] Geankoplis, C.J. (1993) Transport Processes and Unit Operations. Prentice-Hall International, Inc., Upper Saddle River, NJ.

[35] Thomas, H.C. (1944) Heterogeneous Ion Exchange in a Flowing System. Journal of the American Chemical Society, 66, 1664-1666. https://doi.org/10.1021/ja01238a017 